\title{
A Theorisation on the Impact of Responsive Corporate Social Responsibility on the Moral Disposition, Change and Reputation of Business Organisations
}

\author{
Tan Seng Teck ${ }^{1}$, Chang Jau Ho ${ }^{2}$, Liau Chee How ${ }^{3}$, Nanthakumar Karuppiah ${ }^{2} \&$ William Chua ${ }^{4}$ \\ ${ }^{1}$ Senior Lecturer, Faculty of Business, Communication and Law (FOBCAL), INTI International University, \\ Malaysia \\ ${ }^{2}$ Lecturer and Senior Lecturer, University of Hertfordshire Centre, INTI International College, Malaysia \\ ${ }^{3}$ Lecturer, Faculty of Business and Law, Deakin University Melbourne, Australia \\ ${ }^{4}$ Associate Professor, IPE School of Management, Paris, France \\ Correspondence: Tan Seng Teck, Faculty of Business Communication and Law (FOBCAL), INTI International \\ University, Malaysia.
}

Received: August 3, 2018

Accepted: August 29, 2018 Online Published: November 25, 2018

doi:10.5539/jms.v8n4p105

URL: https://doi.org/10.5539/jms.v8n4p105

\begin{abstract}
Corporate social responsibility has been a densely researched area. Research paradigms have evolved significantly stamping from a sociological focus to a more business integrated framework and the currently growing emphasis on quantifying its performance. However, while much literatures champion the proponents of a proactive corporate social responsibility, the contributions of the more responsive version have been largely under studied. This is not an empirical paper. Far from it, this paper attempts to unveil the current literature gaps pertaining to responsive corporate social responsibility. This paper explores the intrinsic contributions of responsive corporate social responsibility on the moral discourse, organisational change and reputation management in an organisation. It theorises the concept of responsive corporate social responsibility as a moderator of external pressures, as a vector of a moral reboot in organisation change and a device for salvaging reputational damage in business organisations. This paper draws from the literature gaps between studies of normative morality and its interaction in principles of general management, organisational change concepts, branding and corporate reputation. It underwrites to examine the moral contents and discourse of business firms when faced with hostile externalities and studies the moral entrails in its organisational change processes and sequentially how this implicates the corporate reputation of a firm. This paper argues that the impacts of responsive corporate social responsibility and its ability to impact moral dispositions in business organisations deserve closer scrutiny. Study on the influence of responsive corporate social responsibility on organisation change and reputational salvage has similarly is also underscored. This article provides a theoretical review of the emerging gaps in corporate social responsibility and prompts that the concept of responsive social responsibility warrants closer attention.
\end{abstract}

Keywords: responsive corporate social responsibility, gaps in literatures

\section{Corporate Social Responsibility: A Labyrinth of Concepts}

Corporate social responsibility (CSR) is a popular but controversial subject. Many penned on this and the literatures accumulated over years have deepened the understanding on this topic. Despite rich academic research and writings, CSR remains a fuzzy concept. Writings are largely unfocused and dispersed that spanned from general socialist duty to broad environmental concerns. Many interpreted the term differently (Sethi, 1975) and the practicality of CSR was delimited by a labyrinth of conflicting ideas and unsystematically connected theories (Wood, 1991). As a consequence, modern business firms are unduly influenced to satisfy all sorts of expectations from a spectrum of stakeholders' demands (Dahlsrud, 2008).

For instance, earlier developments of CSR literatures require corporations to be socially anchored, a momentum which pay premium to establish an all-inclusive business policy by incorporating views of stakeholders through meaningful dialogues (Owen, Macnaghten, \& Stilgoe, 2012). Corporations engage in those responsibilities beyond economic and legal obligations where social acceptance and business legitimacy is highly prized. Modern 
business organisations are required to shift from a singular orientation for profit to one that are "conscious of a multiplicity of purpose (economic, social, psychological, educational, environmental and even political"). Corporations must maintain a socially favourable business environment and a firm's decision making powers are diluted and benchmarked against the requirement to fulfil social needs (Brown \& Perry, 1994). They are obliged to implement socially desirable business policies (Bowen, 1953), one that underscore a firm's corporate citizenship (Wood, 1991) and one that includes a broad spectrum of obligations a firm owed to the society including fulfilling altruistic philanthropic obligations (Carroll, 1979).

Subsequent CSR developments moved away from a socialist discourse. Unlike the socialist approach, positivistic CSR devised purposeful ways to integrate CSR within business (Donaldson \& Dunfee, 1994) and explored how social values could be strategically incorporated within business models. Positivist CSR researchers prompted managers to justify social values within their business decisions (Hosmer \& Kiewitz, 2005) with emphasis placed in providing "a distinctive view of a corporation's overall efforts towards satisfying its obligations to society" (Wartick \& Cochran, 1985). A host of researchers in this genre (see Porter \& Kramer, 2002; Guston, 2004) recommend firms to strategically integrate CSR within their business frameworks. Porter and Kramer's shared value model is particularly attractive, and it was argued elsewhere (see Rakesh et al., 2013) that a strategically integrated CSR contributed to superior financial performance of a firm.

Others rallied for a legal paternalistic approach (See Keith Davis, 1980; Owen et al., 2012). These proponents support the legalisation of stakeholders' moral claims. There are increased codifications of these moral claims under the pretext of the UN Declaration of Human Rights as well as the emergence of the UN Global Compact and the SA8000 certification programme (see Higgins, 2010). Others spawned interests in developing policies and frameworks to govern specific aspects of management. For example, the European Commission developed a unified framework to govern responsible research. EU Commissioner Ma' ire GeogheganQuinn provided glaring support for developing of a framework to regulate responsible innovation where she mentioned:

Research and innovation must respond to the needs and ambitions of society, reflect its values and be responsible...our duty as policy makers (is) to shape a governance framework that encourages responsible research and innovation [Emphasis added] (Geoghegan Quinn, 2012)

Despite significantly evolved, the role of CSR in organisational change is not clearly delineated. This fundamentally raised the question on its true value to spawn moral transformations in organisations (Higgins, 2010). Socialist CSR is superficial and presented merely lip service, nothing more than window dressing. For instance, Carroll argued that a firm devoid of corporate philanthropy does not lose its validity. Corporate philanthropy is a voluntary gesture, an "icing on the cake", to use precisely his words. Positivistic CSR movements, on the other hand, reflect a management genre, one that closely resemble a stakeholder management (see Wood, 1991). If this were so, positivistic CSR lacked ethical core (Weitzner \& Darrach, 2009) and mislead firms to pursue ethical positioning, an overlapping concept between virtue ethics and strategy management (Rakesh et al., 2013). This constrains the application of CSR in areas of practice deemed profitable for business firms and neglects the rights and interests of marginalised groups that are often considered as non-essential stakeholders of a firm.

The biggest concern is that contemporary CSR concepts overemphasised the proactive ability of business entities to instigate social change. There is over assumption that moral disposition in organisations depends on the managers' ability to consciously steer the organisation to achieve better social outcomes. What a business organisation could do for the society is the primary question, one that fell short of explaining a reactive and deeply ingrained moral dispositions in business organisations. Unfortunately, these concepts overlooked the importance on how a business organisation should react and respond to external social pressures. Reactive or responsive CSR precepts require a de-centering and deconstruction of the business organisation (Higgins, 2010). By this, it means that business firms no longer assume a central role to orchestra social change, but instead undertake a deconstructed role in response to socio-structural demands. This reversed assumption of duty is essential as external drivers of change have unlimited ability to generate deeper and more meaningful transformations in a business firm. A transformation challenges the deeper structures of an organisation and is not limited by a firm's imagination of what it could do for the society.

So how does this responsive CSR and moral transformation apply in practise? What is the influence of responsive CSR as a vector of moral transformation in business organisations? Let us assume that by default, a firm commonly usurps utilitarian business values where an act is benchmarked against the ratio of pain and pleasure it generates. However, these firms do not exist in isolation but on the contrary, their freedom constrained within a pluralist society. No matter how utilitarian a firm behaved, it is pivotal that they abide to a minimum level of 
morality (Tan et al., 2018). Now imagine what happens if that firm breaches the minimum content of morality. Obviously, the firm will receive an onslaught of legal, social and political backlash. A punctuated equilibrium in organisational change and a moral transformation would ensue. Such organisation changes quite often reset the moral values of the firm capable of reversing the polarity of the firm's ethical position from utilitarian towards a universalistic one. Let us further consider the case of Shell's mismanagement of the Brent Oil Spar storage buoy saga in the Atlantic to strengthen this point. The saga led to a furious backlash from the public and caused a massive drop in share prices and distorted Shell's brand image. Post the saga, Shell's Annual Report described some interesting sub-conscious reactions towards the socio backlash. The report wrote:

We believe that we acted honorably in both cases. But that is not enough. Clearly, the conviction that you are doing things right is not the same as getting them right. For us at least, this has been a very salutary lesson. We were ready to learn from experiences, however painful, because of a planned process of change begun in 1994. It represented the most thorough and far reaching review for over 30 years-our Transformation. Nothing was sacrosanct, and fundamentals were questioned: the structure, the way business is done, the quality of leadership, relationships with people and our vision of the future (Shell Inc. Annual Report 1998). [Emphasis added]

Shell appeared deconstructed by the punctuated equilibrium that in turn triggered deeply rooted organisational changes. Unlike proactive CSR that pays peripheral attention to assorted social claims, Shell exhibited a moral transformation, a change that transforms the deeper structure of the organisation. A moral shift from utilitarian to universalism. The highlighted words and phrases in the above excerpt prove these salient points. For instance, Shell expressed deep remorse over the incident. The phrases "very salutary lesson" and "however painful" clearly connote a punctuated outcome in Shell. Other phrases indicated that Shell experienced deeply rooted organisational changes. These phrases, "most thorough far reaching-our transformation" where "fundamentals were questioned, including the "structure", "way business is done", "quality of relationships" and even Shell's "vision for the future" vindicated those rooted organizational changes in Shell.

This paper conceptually examines this kind of moral reactions in business firms. A reactive moral transformation that deconstructs and decentres a business firm. A moral transformation activated by externalities that reverse the polarity of a firm's moral presentation, and responsive CSR as a vector in triggering morally rooted revolutions in business firms. This paper addresses three key questions. Firstly, what is the role of responsive CSR in the moral disposition of an organisation? Secondly, what organisational changes do responsive CSR generate in a business organisation and thirdly, what are the contributions of responsive CSR on the restoration of corporate reputation?

\section{Conceptual Gaps in CSR Literatures}

Business firms do not exist in vacuum but conversely are entangled in an open system constituting the pluralistic demands of polarised interests (Davis, 1976). There are gaps between social expectations and the incongruent economic lifestyles of business corporations. Unlike earlier writings that denounced the values of CSR (see Friedman, 1970), many later kinds of literature professed the contributions of CSR as an effective method to manage and mitigate the impacts generated by the gap of these polarised expectations. Keith Davis (1980) for example exhorts the role of proactive CSR stating that firms must keenly anticipate arising discords and take preventive steps in applying measures to address these problems before they become major irritants.

This sort of proactive measures has been repeatedly endorsed in literatures. Carroll (1991) for example proposes a pyramid model sorting out a firm's fundamental legal and discretionary duties on philanthropy. Later theories and writings were more precise, requiring firms to somewhat frame their CSR activities within some measurable business grid. The term corporate social performance (CSP) was devised to measure a broad spectrum of social values that business corporations could contribute (see Newman \& Perry, 1995). A more advanced shared value model was formulated to measure how far CSR movements are captured within a firm's value chain. Porter and Kramer (2002) conceived the "shared value model" where a firm could draw strategic advantage through integrating and establishing a strategic link between CSR and a firm's value chain.

While proactive CSR measures provide a conscious and directional value of ethics, it has been criticised that it lacked a deeper sense making. Basu and Palazzo (2008) argued that positivistic CSR lacks a clear understanding on the cognitive values on how firms interpret the values of CSR within context. This work improved the understanding of CSR and converge some attention to understanding the internal determinants on why and how a firm executes its CSR maneuvers.

There lies the first gap in CSR literatures. While much has been written on proactive CSR, there are few literatures that studied the role of responsive CSR. Keith Davis (1980) interestingly labeled responsive CSR as merely a 
minimum role reflecting a firm's basic response towards a specific social pressure or discontent. Higgins (2010) conversely argued that while proactive CSR could resemble window dressing, responsive CSR could deconstruct the firm amidst strong external pressures. Responsive CSR goes beyond a persuasion to 'do the right thing' but triggers a discourse within the firm's moral values and alters its relationship with the stakeholders (Higgins, 2010). This point is taken further by Tan et al. (2018), where the authors reviewed the role of external pressure on the deconstruction of firms like Shell Inc. and Volkswagen Inc. Such deconstruction triggers a stream of responsive CSR within those firms and a rejuvenation of the moral state of these firms.

It is also apparent that business firms experience deconstruction when they encounter external pressures. It is necessary for organisations to change so that they can adapt to the social shifts. Literatures on organization change are plentiful, but organisation change involving responsive CSR and moral discourse are few. This leads to the second research gap. Earlier model presupposes a triadic mode of planned organisation change (See for example Kurt Lewin's change model) (Georg \& Christian, 2000). Conventional planned models in organisational change postulate a gradual and predictable change in business organisations. Later organisation change models champion a more radical nonlinear approach. Gersick (1991) termed this as a punctuated equilibrium which could generate deep structural alterations and revolutions within the organisation of change.

This theorem is supported elsewhere (see Van De Ven \& Poole, 1995) where the study affirms that organisational change can consist of constructive patterns. Constructive change model explores the role of discontinuous change in the deconstruction of an organisation (see Andrew, 1999; Higgins , 2010). However, these studies shed little understanding on the stimulus of responsive CSR and moral values underlying organisation change and particularly how organisational change, in turn, alters the discourse of the relationship between the firm and its stakeholders. There is a need to fathom the intrinsic meaning behind these changing moral discourses instead of merely focusing on the change process.

There is also a necessity to examine organisation change from an ethnographic perspective. Responsive CSR triggers a moral discourse in organisation change and business firms need to stretch their sociological and organisation imagination to capture the reflexive values rather than the change process itself. An anthropological approach to studying organisation change deserves attention (Yanow et al, 2011) so that there is adequate attention given on the reflexive ideals and making sense on the deeper values of organisation change (see Weick, 1988). The works of Tan et al. (2018) studied this form of moral discourse and reflexivity.

The examples of Shell's repentance from its Brent Oil Spar saga deeply construed an organisation change that was triggered by a swing in a moral discourse which transformed the business and its relationship with the society. A responsive CSR triggered organisation change transcends regular structural change but one that is constructively fortified by a moral reboot and making sense on the deeper derivations of change (Maitlis \& Sonenshein, 2010).

Finally, it is anticipated that business firms often sustain reputational damage post crises and punctuated change. However, it has also been long recognised that CSR is an effective tool to restore a firm's reputational damage post crises (Kim, 2014). But other studies (see for example Fein \& Hilton, 1990) vindicate that the impact of CSR on the reputation of an organisation post crisis varies. Studies epitomized that if consumers are suspicious on the true intention and motive of a company's CSR, it might generate further repercussions for the company instead of improving the image of the company.

CSR activities may not only be inefficient but also self-defeating and backfire. This causes the companies to suffer further reputational loss. For example, Philip Morris anti-smoking campaign for the youths backfired and critics questioned and criticised the organisation's intention of the CSR campaign (Fairclough, 2000). This paper argues that most of the prior researches focused on the potential impact of proactive CSR on reputation redemption. The contribution of responsive CSR derived from a morally deconstructed firm on reputation redemption could yield different results (see Yeosun et al., 2006). Figure 1 below illustrates the conceptual framework of a plaucible study on responsive CSR. 


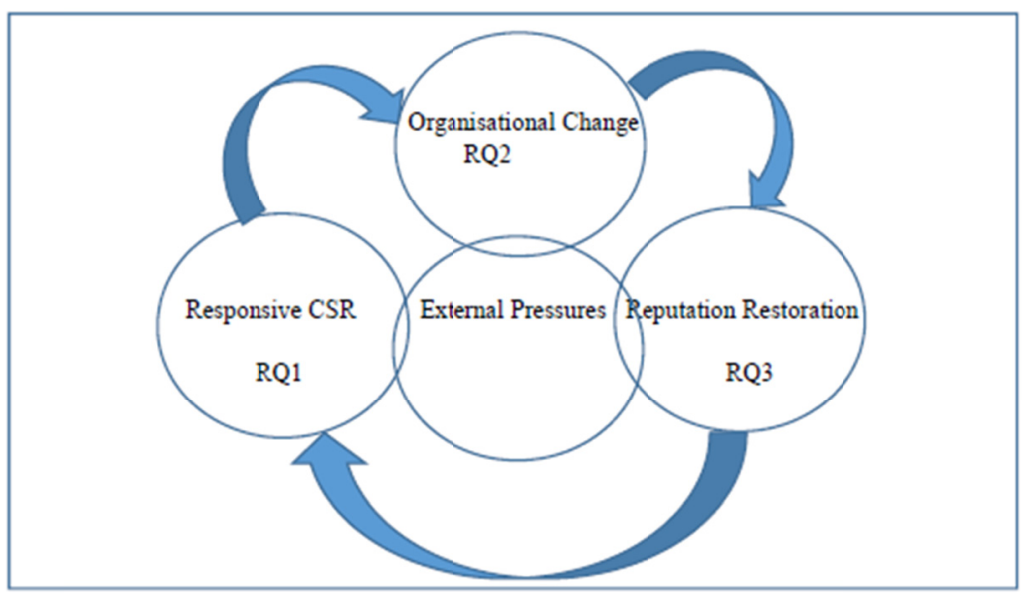

Figure 1. The conceptual framework

Source: Literature Review.

Figure 1 above illustrates the logical progression of this research. Business firms are exposed to mundane but unique external pressures. These external demands trigger a punctuated upheaval requiring a business organisation to usurp a responsive CSR and mitigate the impact of accumulated pressure (RQ1). Responsive CSR further instigates a more abstract and philosophical change that deconstructs the firm that alters its moral disposition leading to deep structural and anthropological changes within the firm (RQ2). A deconstructed firm with a 'moral reboot' permeated with responsive CSR is likely to redeem post crisis reputational loss (RQ3). Diagram 1 above synthesises the parameters of emerging gaps in CSR literatures.

\section{The Implications of the Research Gaps}

The discussions above explore some salient gaps within the writings on CSR. Primarily, many previous studies emphasised the role of proactive CSR in mitigating the effects of pressures on the business environment. Proactive CSR was hailed as a driver of organisation innovation (see Bocquet, Le Bas, Mothe, \& Poussing, 2003), a model to measure corporate business performance (Carroll, 1979) and an inextricable means to generate competitive advantage (see Porter \& Kramer, 2002). These literatures view CSR as a form of proactive measure where firms eagerly anticipate potential external pressures and take active steps to eliminate them before they become a challenge. Keith (1979) argued that proactive CSR is a 'better' means to solve uprising social problems triggered by the incompatibility between the lifestyle of business firms and expectations of the society. However, very few literatures have explored the true values of responsive CSR. Unlike proactive CSR, responsive CSR requires a firm to respond to specific issues and turbulence. While Keith labels responsive CSR as merely 'a minimum measure', the works of some authors (see Higgins, 2010; see also O'Dwyer, 2003) conversely maintained that proactive CSR overlooks the broader questions of social process and organisation change. It prevents a deeper understanding on the deconstruction of a business firm and its underlying moral disposition when a firm responds to social pressure. Responsive CSR triggers intrinsic re-delineation of moral values and redefines the relationship between an organisation and its stakeholders. The works of Tan et al. (2018) fortified this sort of change and moral re-delineations in cases such as the Volkswagen Inc. scandal and the Shell Inc. Brent Oil Spar saga.

Although the literatures on organisation change are 'mature', it received little conceptual developments since. This presents the second gap within the literatures. Original discords within the literatures in organisation change revolve around the purviews of planned versus punctuated change with much ink spilled on theorizing resistance and or strategies to change (Georg \& Christian, 2000). Previous literatures on organisation change presuppose the pervasive external and internal forces of change and particularly how the change can be effectively managed. However, the body of literature is currently overwhelmed with a rationalistic model of change, presupposing the firm's ability to control the change process leaving the idea on the deconstruction of a firm and the moral content of organisation change malnourished. Far and few literatures have attempted to examine the organisation's moral content, conscience and sense making in the event of a change. Much works was written to comprehend the change process but fewer works were devoted to understand the moral cognition an organisation encounters when they go through change. Very few literatures have addressed the idea of 'moral reboot' when a firm is faced with a change. 
Finally, many earlier works demonstrated the value of CSR as a strategic tool for redeeming corporate reputation (see for example Vanhamme \& Grobben, 2009). However, recent literatures cautioned against an unguarded reception of CSR to mitigate a crisis (see Yeosun et al, 2006). This literatures informed that CSR executions hidden with ulterior motive might cause further reputational damage. The body of literatures as it currently stands present a primary knowledge gap. While many previous studies examined the role of proactive CSR as a crisis moderator, literature on the role of responsive CSR in corporate branding is lacking.

\section{Conclusion}

This paper is never meant to share empirical results but more important, it opens a new frontier of research opportunities in responsive CSR. While much emphasis has been shed on the role of proactive CSR, the essence of responsive CSR and its role on the moral disposition, change and organisation reputation has been understudied. This paper sparks the momentum for a possible study on the influence of responsive CSR in deconstructing a business firm, altering its moral disposition, initiating deep rooted change and rethinking the corporate approach to branding. A deeper understanding on the reflexive values of responsive CSR provides a truly intrinsic understanding on corporate study transcending beyond merely lip service applications.

\section{References}

Andrew, W. (1999). Punctuated Equilibrium: Reconciling Theory of Revolutionary and Incremental Change. $\begin{array}{llllll}\text { System Research } & \text { Bnd }\end{array}$ https://doi.org/10.1002/(SICI)1099-1743(199907/08)16:4<359::AID-SRES253>3.0.CO;2-V

Basu, K., \& Palazzo, G. (2008). Corporate Social Responsibility: A Process Model of Sensemaking. Academy of Management Review, 33(1), 122-136. https://doi.org/10.5465/amr.2008.27745504

Bocquet, R., Le Bas, C., Mothe, C., \& Poussing, N. (2003). Are firms with different CSR profiles equally innovative? Empirical analysis with survey data. European Management Journal, 31(6), 642-654. https://doi.org/10.1016/j.emj.2012.07.001

Bowen, H. R. (1953). Social responsibilities of the businessman. New York: Harper \& Row

Brown, B., \& Perry, S. (1994). Removing the financial performance halo from Fortunes Most Admired Companies. Academy of Management Journal, 37, 1346-1359.

Carroll, A, (1979). A three-dimensional conceptual model of corporate social performance. Academy of Management Review, 4, 497-505.

Carroll, A, (1991). The Pyramid of Corporate Social Responsibility: Toward the Moral Management of Organisational Stakeholders. Business Horizon, pp. 39-48. https://doi.org/10.1016/0007-6813(91)90005-G

Dahlsrud, A. (2008). How corporate social responsibility is defined: an analysis of 37 definitions. Corporate Social Responsibility and Management Journal, 15(1). https://doi.org/10.1002/csr.132

Davis, K. (1980). Social Responsibility is Inevitable. California Management Review, XIX(1). https://doi.org/10.2307/41164678

Donaldson, T., \& Dunfee, T. W. (1994). Towards a Unified Conception of Business Ethics: Integrative Social Contracts Theory. Academy of Management Review, 19(2), 252-284. https://doi.org/10.5465/amr.1994.9410210749

Fairclough, G, (2000) "Philip Morris Removes Slogan From Ads In Second Attempt Responding To Critics," Wall Street Journal.

Fein, S., Hilton, J. L., \& Miller, D. T. (1990). Suspicion of ulterior motivation and the correspondence bias. Journal of Personality and Social Psychology, 58, 753-764. https://doi.org/10.1037/0022-3514.58.5.753

Friedman, M, (1970). The Social Responsibility of Business is to Increase its Profits. New York Times Magazine, $\mathrm{p} 33$.

Geoghegan Quinn (2012), "Science in Dialogue Conference - Towards a European Model for Responsible Research and Innovation", European Commission, Opening address, Denmark. Available at https://ec.europa.eu/research/swafs/pdf/pub_archive/maire-geoghegan-quinn-opening-speach23042012_en. pdf (Last accessed, $20^{\text {th }}$ November, 2018).

Georg, S. \& Christian, N. (2000). Reframing Change in Organisations: The equilibrium logic and beyond. Academy of Management Proceedings, ODC, B.

Gersick, C. J. G. (1991). Revolutionary Change Theories: A Multilevel Exploration of the Punctuated 
Equilibrium Paradigm. The Academy of Management Review, 16(1). https://doi.org/10.5465/amr.1991.4278988

Guston, D. H. (2004) 'Responsible innovation in the commercialised university'. In: Stein, D. G. (ed.) Buying in or Selling Out: The Commercialisation of the American Research University, pp. 161-74. New Brunswick: Rutgers University Press.

Higgins, C. (2010). Is a Responsive Business also a Responsible Business? Journal of Business Systems, Governance and Ethics, 5(3).

Hosmer, L., \& Kiewitz, C. (2005). Organizational justice: A behavioral science concept with critical implications for business ethics and stakeholder theory. Business Ethics Quarterly, 15(1), 67-91. https://doi.org/10.5840/beq20051513

Kim, S. (2014). What's Worse in Times of Product-Harm Crisis? Negative Corporate Ability or Negative CSR Reputation? J Bus Ethics, 123, 157-170. https://doi.org/10.1007/s10551-013-1808-X

Maitlis, S., \& Sonenshein, S. (2010). Sensemaking in Crisis and Change: Inspiration and Insights from Weick. Journal of Management Studies, 47(3). https://doi.org/10.1111/j.1467-6486.2010.00908.x

Newman, S., \& Perry, Jr. (1995). Business, Government, \& Society: Management competitiveness, Ethics, and Social Issues. Englewood Cliffs, NJ: Prentice-Hall, Inc.

O'Dwyer, B. (2003). Conceptions of corporate social responsibility: The nature of managerial capture. Accounting, Auditing and Accountability, 16(4), 523-557. https://doi.org/10.1108/09513570310492290

Owen, R., Macnaghten, P., \& Stilgoe, J. (2012). Responsible Research and Innovation: From Science in Society to Science for Society, with Society. Science and Public Policy, 39(6), 751-760. https://doi.org/10.1093/scipol/scs093

Porter, M. E., \& Kramer, M. R. (2002). The Competitive Advantage of Corporate Philanthropy. Harvard Business Review, p. 516.

Rakesh, S., Tan, S. T., \& Yap, S. F. (2013). A Critical Review of Porter's Integrated Approach towards Corporate Social Responsibility. International Journal of Business and Management Tomorrow, 3(8).

Sethi, S. P. (1975), Dimensions of Corporate Social Performance: An Analytical Framework. California Management Review, 17(3), 58-64. https://doi.org/10.2307/41162149

$\begin{array}{llll}\text { Shell Annual } & \text { Report. } & \text { (1998). } & \text { Retrieved }\end{array}$ http:/www.shell.com/sustainability/sustainability-reporting-and-performance-data/sustainability-reports/pre vious/_jcr_content/par/expandablelist/expandablesection_332888471.stream/1454157664246/7419d7c0b96 ee36e92059e205107e3106d35d9d8f3a4909c8523f49ded9e4727/shell-sustainability-report-1998-1997.pdf

Tan, S. T., Liau, C. H., Nanthakumar, K., \& Chang, J. H. (2018). Universalism and Utilitarianism, Two Worlds Apart or Inextricably Linked? Journal of Management and Sustainability, 8(1).

Van De Ven, A. H., \& Poole, M. S. (1995). Explaining Development and Change in Organizations. Academy of Management Review, 20(3), 510-540. https://doi.org/10.5465/amr.1995.9508080329

Vanhamme, J., \& Grobben, B. (2009). Too Good to Be True!. The Effectiveness of CSR History in Countering Negative Publicity. Journal of Business Ethics, 85, Supplement 2: Corporate Social Responsibility Implementation, 273-283.

$\begin{array}{llll}\text { Volkswagen } & \text { Annual } & \text { Report. } & \text { (2016). }\end{array}$ https:/www.volkswagenag.com/presence/investorrelation/publications/annual-reports/2017/seat/SEAT_201 6_ING.pdf

Wartick, S. L, \& Cochrane, P. L. (1985). The evolution of the corporate social performance model. Academy of Management Review, 10(4), 758-769. https://doi.org/10.5465/amr.1985.4279099

Weick, K. E. (1988). Enacted sensemaking in crisis situations. Journal of Management Studies, 25, $305-317$. https://doi.org/10.1111/j.1467-6486.1988.tb00039.x

Weitzner, D., \& Darroch, J. (2009). A Comprehensive Framework for Strategic CSR: Ethical Positioning and Strategic Activities. Academy of Management Annual Meeting Proceedings, 6(6), 1-6. https://doi.org/10.5465/ambpp.2009.44252605

Wood, D. J. (1991), Corporate Social Performance Revisited. The Academy of Management Review, 16(4), 691-718. https://doi.org/10.5465/amr.1991.4279616 
Yanow, D., Ybema, S., \& van Hulst, M. (2011). The Practice of Qualitative Organizational Research: Core Methods and Current Challenges as cited in Gillian Symon and Catherine Cassell (Eds.), Part II: Core Methods of Qualitative Inquiry in Organizational Research. London: Sage (forthcoming Winter 2011-2012).

Yeosun, Y., Gurhan, Z., \& Schwarz, N. (2006). The Effect of Corporate Social Responsibility (CSR) Activities on Companies with Bad Reputations. Journal of Consumer Psychology, 16(4), $377-390$. https://doi.org/10.1207/s15327663jcp1604_9

\section{Copyrights}

Copyright for this article is retained by the author, with first publication rights granted to the journal.

This is an open-access article distributed under the terms and conditions of the Creative Commons Attribution license (http://creativecommons.org/licenses/by/4.0/). 